\title{
Lack of CD I I 7 and rare bcl-2 expression in stomach cancer by immunohistochemistry. An immunohistochemical study with review of the literature
}

\author{
Masoud Mireskandari*1, Ali Fakhr Shafaii ${ }^{1}$, Gian Kayser ${ }^{2}$ and Klaus Kayser ${ }^{3}$
}

Address: ${ }^{1}$ Afzalipour Hospital, Pathology Department, Kerman University of Medical Sciences, Kerman, Iran, ${ }^{2}$ Department of Pathology, University Freiburg, Freiburg, Germany and ${ }^{3}$ UICC-TPCC, Charite, Berlin, Germany

Email: Masoud Mireskandari* - mireskandari@gmail.com; Ali Fakhr Shafaii - fakhrshafai@yahoo.com; Gian Kayser - gian.kayser@uniklinikfreiburg.de; Klaus Kayser - klaus.kayser@charite.de

* Corresponding author

Published: 16 May 2006

Diagnostic Pathology 2006, I:7 doi:10.1 186/1746-1596-1-7
Received: 26 December 2005

Accepted: 16 May 2006

This article is available from: http://www.diagnosticpathology.org/content/I/I/7

(c) 2006 Mireskandari et al; licensee BioMed Central Ltd.

This is an Open Access article distributed under the terms of the Creative Commons Attribution License (http://creativecommons.org/licenses/by/2.0), which permits unrestricted use, distribution, and reproduction in any medium, provided the original work is properly cited.

\begin{abstract}
Background: Gastric adenocarcinoma is one of the most frequent malignancies worldwide including Iran. This study was designed to immunohistochemically evaluate the CDII7 and bcl-2 expression in gastric carcinomas and their potential use as therapeutic targets in the treatment of patients with advanced stage gastric cancer.

Materials and methods: Representative paraffin blocks obtained from 38 operated gastric adenocarcinoma patients were retrieved from Afzalipour Hospital pathology department archive, Kerman, Iran. Immunohistochemical analysis (IHC) for CDII7 was carried out in all cases including negative (normal gastric epithelium) and positive (Gastrointestinal Stromal Tumor) controls. In addition, the cases were evaluated immunohistochemically for apoptosis-related protein (bcl-2), to evaluating a potential association of CDII7 expression with the cell proliferation regulatory pathways.

Results: No positive reaction for CDII7 was seen in gastric carcinoma tumor cells irrespective to the cell type, grade, and stage, proliferation and apoptosis rate. Expression of bcl-2 was observed in only one case.

Conclusion: We conclude that CDII7 overexpression detectable by immunohistochemistry does not play a significant role in gastric carcinoma pathways and development, although overexpression at the gene level and/or mutated CDI 17 expression might exist. Thus, it is unlikely that the CDII7 pathway is of clinical significance in gastric carcinoma patients.
\end{abstract}

\section{Background}

Gastric carcinoma is the second most frequent malignancy in the world constituting about $10 \%$ of newly diagnosed malignancies and accounting for more than $12 \%$ of cancer deaths [8]. It is the disease of the elderly with a median age of 72 years in American patients at the time of diagnosis [8]. Immunohistochemically (IHC), almost all tumors are positive for cytokeratin and epithelial membrane antigen [43]. Furthermore, gastric carcinomas have been shown to be positive for following factors in different proportions: Pancreatic Secretory Trypsin Inhibitor (76\% and $89 \%$ in intestinal and diffuse types respectively) 
[19], carcinoembryonic antigen (30-55 \%), Villin (47 \%), Beta Catenin (63\%), CD44 (55-58\%), [22,43] and Placental Alkaline Phosphatase (23\%) [49]. Mutations of the p53 protein and abnormalities of the Adenomatous Polyposis Coli (APC) gene were found in about $50 \%$ of cases [1]. In the literature, only one study examining the expression of CD117 in gastric carcinomas exists to our knowledge until now [18]. This study reports an expression of the protooncogene c-kit and its ligand stem cell factor (SCF) in gastric carcinoma cell lines [18]. In vivo, the potential expression of the protein in human gastric carcinoma has not been analyzed, and no statement about the potential clinical significance of the in vitro study has been given to our knowledge.

Classically gastric carcinomas are classified to intestinal and diffuse type according to the Lauren classification [29]. Although the role of adjuvant therapies in advanced gastric cancer is under debate, generally surgical resection is considered as the standard therapy and response to other methods of treatment is poor [46].

Gastric carcinomas are usually detected at advanced tumor stages. The factors involving the miss an early diagnosis comprise anatomical and clinical reasons. Anatomically, the stomach has a very large luminal space and the tumors can reach quite a large size prior to inducing pain or symptoms of obstruction. From the clinical point of view, symptoms of gastric carcinoma are equivalent to benign lesions such as chronic gastritis or peptic ulcer. Often, these lately diagnosed tumors are no longer amenable to surgery. Population based gastric cancer screening programs have not been implemented in most countries due to lack of sensitive and specific serum tumor markers, high economic burden, and poor compliance of routine gastroscopy.

Thus, it seems reasonable to investigate in new therapeutic modalities for advanced gastric cancer. Immunotargeting and blocking specific tumor growth pathways is one of the new promising strategies. Successful examples include regimes against CD20 and Her-2-neu in non-Hodgkin's B cell lymphoma (NHL) and advanced stage breast carcinoma, respectively $[5,23]$. Chimeric anti-CD20 antibody (rituximab) sensitizes B cells in NHL to inducing apoptosis by cytotoxic substances, for example, by diminishing the Bcl-x expression [23]. Inhibitor of Her-2-neu protein (trastuzumab) has been reported to induce a $19 \%$ response rate in metastatic breast carcinoma patients [5]. An additional agent is associated with the expression and inhibition of CD117 (c-kit), and has been effectively used in various neoplasms such as hematological malignancies and gastrointestinal stromal tumors (GIST). Thus, these inhibitors could be potentially considered as a new target for therapeutic regimes in gastric carcinomas; however, only if a significant CD117 expression could be demonstrated, i.e., by use of IHC.

\section{Expression of CDI I7, c-kit and the stem cell factor (SCF) receptor}

CD117 is coded by the c-kit protooncogene on chromosome 4q11-q12 [42]. Being a cell surface protein it is categorized into the third variety of cell receptors named receptors with intrinsic kinas activity [10]. It possesses three domains of extra cellular, intracellular, and transmembrane location. Related receptors include the granulocyte colony stimulating factor (G-CSFR) and platelet derived growth factor (PDGFR). The extra cellular domain possesses five immunoglobulin-like areas. The first three are responsible for binding with stem cell factor (SCF). Following a complex formation with SCF the intracellular domain is phosphorylated and new sites are provided for cytoplasmatic messengers e.g. IP3, Src, and ras. Following these events, the cell is committed for entering the $S$ phase and cell proliferation cycle [30].

The expression of the CD117 protein has been identified in different cells types, such as osteoclasts, Langerhans cells, cord blood cell, renal tubules epithelial cells, sweat gland cells, or megakaryocytes [3]. It probably plays a physiologic role in the proliferation of these cells. A significant influence of C-kit in the formation and growth of extremities at embryonic stages has been suspected by animal model studies [41]. Mast cells are dependent on the autocrine circle of CD117 [1], and the loss of CD117 in germinal cells of embryonic testis results in an increased apoptosis of germ cells and infertility in the following life periods [13]. Soluble c-kit can mobilize bone marrow cells into the peripheral blood via the interaction with the vascular cell adhesion molecule 2 (VCAM-2) [35]. Both, SCF and CD117 take influence on the growth of endothelial cells and smooth muscle cells of the umbilical vein [33]. However, the main function of CD117 is the activation of the cell proliferation. Expression of CD117 has been noted in a subset of angiosarcoma cases, a phenom-

Table I: Immunohistochemical detection of CDI I 7 in malignant tumors

\begin{tabular}{lll}
\hline Tumor Type & $\begin{array}{l}\text { Reactivity } \\
(\%)\end{array}$ & $\begin{array}{l}\text { Number of } \\
\text { cases studied }\end{array}$ \\
\hline Endometrial carcinoma & 100 & 8 \\
Follicular carcinoma of thyroid & 100 & 11 \\
Papillary carcinoma of thyroid & 100 & 9 \\
Merkel cell carcinoma & 96 & 22 \\
Seminoma & 96 & 65 \\
Ovarian serous cystadenocarcinoma & 94 & 16 \\
Renal cell carcinoma, chromophobe & 90 & 74 \\
Osteogenic sarcoma & 84 & 18 \\
\hline
\end{tabular}


Table 2: Details of demographic, microscopic, pathologic and immunohistochemical findings in the study cases

\begin{tabular}{|c|c|c|c|c|c|c|c|}
\hline Ser. No. & Sex & Age & $\begin{array}{l}\text { Year of } \\
\text { Operation }\end{array}$ & Location & Cell Type & Grade & Stage \\
\hline I & $\mathrm{F}$ & 50 & 1999 & $A$ & $D$ & - & IIIB \\
\hline 2 & $\mathrm{~F}$ & 48 & 1999 & DI & $\mathrm{D}$ & - & IV \\
\hline 3 & $M$ & 70 & 1999 & B & $\mathrm{D}$ & - & IIIA \\
\hline 4 & $\mathrm{~F}$ & 65 & 1999 & $A$ & 1 & PD & IIIA \\
\hline 5 & $M$ & 58 & 1999 & $A$ & $\mathrm{D}$ & - & IIIA \\
\hline 6 & $M$ & 59 & 1999 & DI & $\mathrm{D}$ & - & IIIA \\
\hline 7 & $M$ & 75 & 1999 & B & 1 & MD & IIIA \\
\hline 8 & $M$ & 28 & 2000 & $A$ & $\mathrm{D}$ & - & IIIB \\
\hline 9 & $M$ & 65 & 2000 & $A$ & $\mathrm{D}$ & - & II \\
\hline 10 & $\mathrm{~F}$ & 65 & 2000 & A & 1 & WD & IIIB \\
\hline II & $\mathrm{F}$ & 54 & 2001 & $A$ & $\mathrm{D}$ & - & IIIA \\
\hline 12 & $M$ & 70 & 2001 & B & 1 & PD & IIIA \\
\hline 13 & $M$ & 70 & 2001 & C & D & & IV \\
\hline 14 & $M$ & 45 & 2001 & C, B & I & PD & IIIB \\
\hline 15 & $M$ & 60 & 2001 & $A$ & 1 & MD & II \\
\hline 16 & $M$ & 51 & 2001 & A & 1 & MD & IIIB \\
\hline 17 & $\mathrm{~F}$ & 67 & 2001 & B & $\mathrm{D}$ & - & IIIB \\
\hline 18 & $\mathrm{~F}$ & 67 & 2002 & C & $\mathrm{D}$ & - & IIIB \\
\hline 19 & $M$ & 39 & 2002 & C & I & WD & IIIA \\
\hline 20 & $\mathrm{~F}$ & 79 & 2002 & B & 1 & MD & IIIA \\
\hline 21 & $\mathrm{~F}$ & 44 & 2002 & DI & $D$ & - & IIIA \\
\hline 22 & $M$ & 63 & 2002 & A & 1 & WD & IB \\
\hline 23 & $M$ & 48 & 2002 & $A$ & 1 & PD & IIIB \\
\hline 24 & $M$ & 52 & 2002 & DI & $D$ & - & IIIB \\
\hline 25 & $M$ & 68 & 2002 & A & I & WD & II \\
\hline 26 & $M$ & 70 & 2002 & $A$ & I & WD & IIIA \\
\hline 27 & $M$ & 88 & 2002 & $A$ & I & PD & IIIA \\
\hline 28 & $\mathrm{~F}$ & 30 & 2003 & C & 1 & MD & IIIA \\
\hline 29 & $M$ & 53 & 2003 & C & I & WD & IB \\
\hline 30 & $\mathrm{~F}$ & 53 & 2003 & C & 1 & MD & IIIB \\
\hline 31 & $\mathrm{~F}$ & 60 & 2003 & - & i & PD & IIIB \\
\hline 32 & $\mathrm{~F}$ & 48 & 2003 & A & $D$ & & IIIB \\
\hline 33 & $M$ & 42 & 2003 & $A$ & Mucinous & WD & IIIA \\
\hline 34 & $M$ & 65 & 2003 & B & $D$ & - & IIIB \\
\hline 35 & $M$ & 45 & 2003 & DI & $D$ & - & IIIA \\
\hline 36 & $M$ & 23 & 2003 & GEJ & I & WD & IIIA \\
\hline 37 & $M$ & 58 & 2003 & A & $D$ & - & IIIB \\
\hline 38 & $\mathrm{~F}$ & 35 & 2003 & $A$ & 1 & PD & IIIB \\
\hline
\end{tabular}

Abbreviations: M: male; F: female; A: antral; B: body; C: cardia; DI: diffuse infiltrative; GEJ: gastro-esophageal junction; D: diffuse type; I: intestinal type; PD: poorly differentiated; MD: moderately differentiated; WD: well differentiated.

enon that has been compared to the action of an oncofetal protein or its anti-apoptotic effect [9].

In man, CD117 proto-oncogene mutations result in an autosomal dominant disease named piebaldism [24]. Somatic mutations have been recorded in various tumor cell types. The mutation of the c-kit protooncogene has been frequently observed in germ cell tumors, particularly in seminoma [25].

Although an over-expression of CD117 mRNA was noted in cell lines of malignant fibrous histiocytomas [36], IHC evaluation of such tumors for c-kit revealed only one positive reaction out of 43 cases [51]. Immunohistochemi- cally, expression of CD117 also has been demonstrated in leiomyosarcomas of the uterus [39], and has been identified in about $50 \%$ of small cell or large cell neuroendocrine lung carcinomas [2]. Over-expression of CD117 is almost always seen in GIST [42]. Immunohistochemically, its expression usually serves for diagnostic differentiation of these tumors from morphologically similar neoplasms [15]. Singular CD117 expression or in combination with that of SCF is noted in several hematopoetic tumors including mast cell leukemia, acute myelogenous leukemia, and other myeloproliferative disorders [10]. In fact, the c-kit expression in acute leukemia can be considered as an indicator of myeloid origin of tumor cells [10] as it is rarely expressed in lymphoid blast cells. Meanwhile 


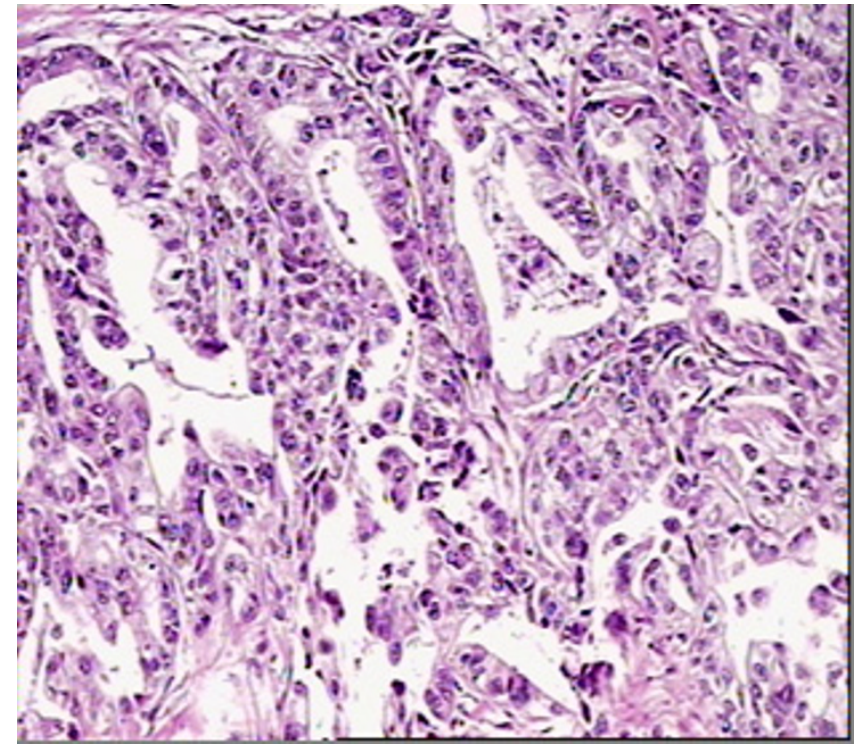

Figure I

H\&E appearance of intestinal type gastric cancer.

its expression in myeloid cells forms the basis for detecting a minimal residual disease (MRD) by flow cytometry [10]. Most tumor cells in Hodgkin's disease including mononuclear and Reed-Sternberg cells express c-kit [10]. Colon carcinomas rarely display a positive cytoplasmatic reaction for CD117 by IHC [40]. C-kit expression varies to a great extent in soft tissue sarcomas, and ranges from $10 \%$ in myxoid sarcomas to $60 \%$ in melanocytic schwannomas [21]. In human gliomas c-kit is widely expressed

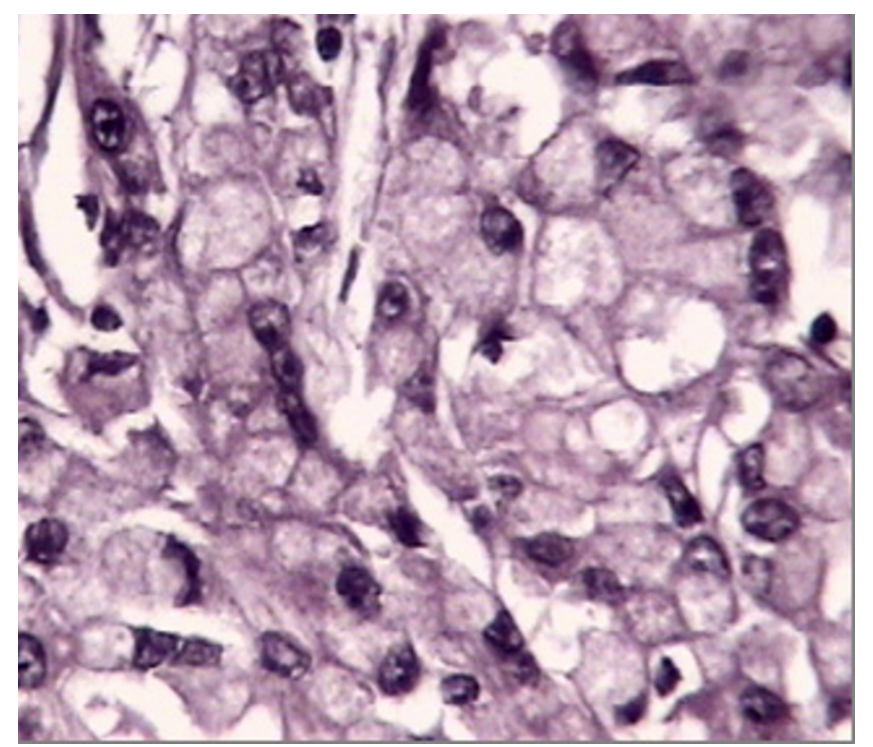

Figure 2

$\mathrm{H} \& \mathrm{E}$ appearance of diffuse type gastric cancer. and an autocrine pathway of tumor activation and progression by c-kit and its ligand has been suggested herein [17]. Interestingly, normal breast epithelial cells abundantly express c-kit, whereas a loss of c-kit expression has been reported in $80-90 \%$ of breast cancer cases [37]. In vitro, the transfer of the c-kit gene into a breast cancer cell line resulted in the suppression of cellular growth [37]. These observations suggest an inhibitory effect of c-kit and its ligand in breast cancer proliferation. One study reports a co expression of c-kit and stem cell factor genes in breast carcinoma and a possible autocrine activation of these cancer cells [20]. A survey of malignant tumors with positive CD117 immunohistochemical reactivity is listed in table 1 according to [22].

\section{Inhibitors of c-kit}

Some endogenous cytokines have shown to posses inhibitory effects on the c-kit receptor [6,28]. Such endogenous inhibitors including TGF $\beta 1$ and IL4 were successfully applied in experimental animals and in colon carcinoma cell lines $[6,28]$. One of the protein tyrosine kinase inhibitors, SU5614 can induce cellular growth arrest and apoptosis in AML by inhibiting the c-kit receptor [45]. STI571 or Imatinib Mesylate is another molecule representing the exogenous inhibitor. Originally applied for the treatment of CML by inhibiting 9;22 the translocation induced tyrosine kinase [44], it later served for an effective treatment of a variety of malignancies including metastasizing gastrointestinal stromal tumors [12]. The treatment with c-kit inhibitors in 21 patients with AML who were partly resistant to chemotherapy was promising too [27]. In vitro studies of small cell lung carcinoma cell lines showed a synergistic effect for c-kit and IGF-1R inhibitors in the induction of apoptosis $[9,48]$. Other in vitro studies dis-



Figure 3

Negative immunohistochemical reaction for CDI I 7 in gastric carcinoma tumor cells. 


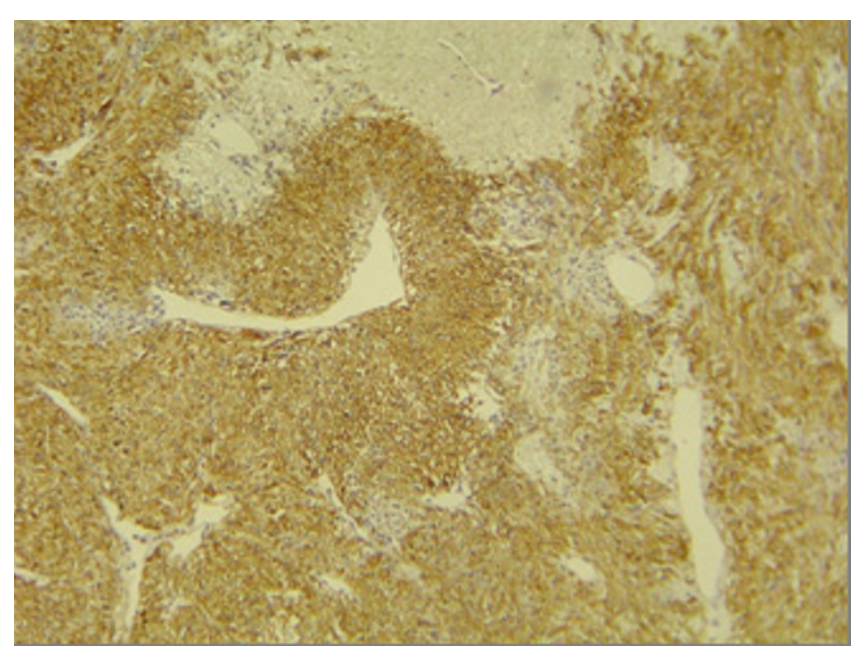

Figure 4

Immunohistochemical staining for CDII7 shows strong diffuse positive reaction in control slide (GIST). Note absence of background staining in non-neoplastic elements at the top of image.

played an inhibition of cell proliferation and induction of apoptosis in colon carcinoma [4], breast carcinoma [37], Ewing sarcoma [16] and neuroblastoma cell lines [7]. In addition, a successfully treated case suffering from a hepatocellular carcinoma and liver cirrhosis has been described [38].

\section{Bcl-2 protein}

$\mathrm{Bcl}-2$ protein is a $26 \mathrm{Kd}$ protein with the major role in controlling apoptosis. Bcl-2 production is controlled by a gene located on chromosome 18 [14]. Bcl-2 belongs to a family of proteins which includes Bax protein [31]. Bax counteracts the effects of bcl- 2 by increasing cell susceptibility to apoptotic stimuli [31]. In fact it is appeared that the ratio of bcl-2 to Bax proteins control the sensitivity or resistance of many cell types to apoptotic stimuli [31]. Although the role of bcl-2 protein is well known in some forms of low grade lymphomas, including follicular lymphomas [14], its role in other cancers is under investigation. Studies could show the reactivity of tumor cells in gastric carcinoma for bcl-2 with various frequencies $[14,50]$. A higher frequency of apoptosis was shown in gastric dysplasia rather than in coexisting gastric carcinoma [50]. This observation is suggestive for a specific role of Bcl-2 in gastric carcinoma development through increasing cell life and imposing it to more genetic alterations [50].

Although these observations are now far from practical implementation in gastric cancer treatment, some reports of successful application of apoptosis induction in gastric cell lines are present $[32,26]$.

\section{Materials and methods}

Paraffin blocks of 38 cases with gastric carcinoma operated on between $11^{\text {th }}$ March 1999 and $5^{\text {th }}$ September 2003 were collected from the archive of the Pathology Laboratory of the Afzalipour Hospital. Representative tumor blocks were selected for immunohistochemistry. A paraffin block of a case with a gastrointestinal stoma tumor (GIST) was used for positive control. Immunohistochemistry was performed by application of the Avidin-Biotin Complex $(A B C)$ method for CD117 and bcl-2. Both primary antibodies and LSAB visualization kit were commercially available from DAKO, Copenhagen, Denmark. The heat induced method (HIER) was applied for antigen retrieval by tris-EDTA buffer PH9. The primary antibody dilution was set to $1 / 400$ for CD117 and to $1 / 40$ for bcl-2 respectively. The deparaffinized and rehydrated slides were incubated with the primary antibodies for 20 minutes, after thorough washing with the secondary antibody for $10 \mathrm{~min}$ utes, with streptavidin for 10 minutes, and liquid Diaminobenzydine (DAB) for 5 minutes. Cases were grouped positive if a dark brown reaction in the tumor cells was noted.

\section{Results}

The complete list of the 38 cases is given in table 2. The spectrum of the patients' age ranges from 23 to 88 years (mean 56). The sex ratio (men/women) accounts to 1.7:1. Twenty patients underwent a total gastrectomy, the others were treated by subtotal gastrectomy. Six of the tumors developed from the cardiac region $(15 \%)$, additional six tumors from the corpus area $(15 \%)$, and 18 cases were located in the antrum (47\%). In 6 cases (15\%) the tumor extensively infiltrated the stomach, and a detailed loca-

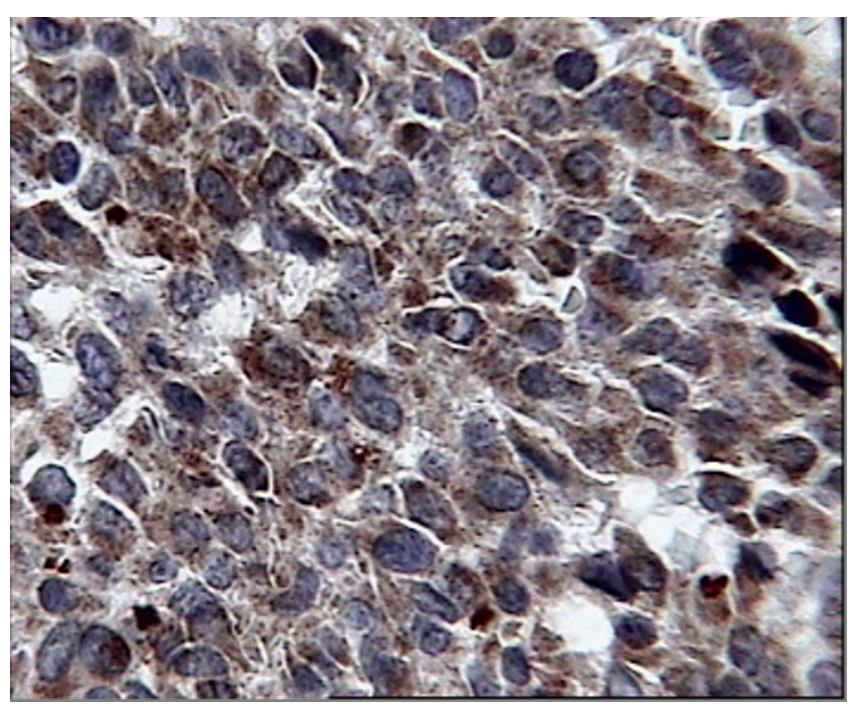

Figure 5

Strong and diffuse cytoplasmic reactivity for bcl-2 in case II. 
tion of the tumors could not be identified. One case originated from gastro-esophageal junction and another single case infiltrated both the body and the cardia. According to the Lauren classification 20 cases (52.6\%) were grouped into the intestinal type (figure 1) and 17 cases $(44.7 \%)$ were grouped into the diffuse type (figure $2)$. One mucinous type was seen $(2.7 \%)$. Within the group of intestinal type tumors 8 cases were well, and 12 cases moderately or poorly differentiated. Most of the patients were operated on in advanced tumor stages showing only two cases at stage I (5.3\%) and 3 cases at stage II $(7.9 \%)$. The advanced stages include 16 cases $(42.1 \%)$ at stage IIIA, 15 cases (39.4) at stage IIIB, and 2 cases $(5.3 \%)$ in stage IV according to the rules of the AJCC/UICC [43].

The CD117 IHC reaction was negative in all cases including the normal surface and glandular epithelium, dysplastic epithelial cells around the tumor, and the invasive components of gastric carcinoma cells (figure 3) while positive control (GIST) revealed strong and diffuse cytoplasmic reactivity (figure 4). The IHC staining for bcl-2 was also negative in all cases except for one case of a diffuse gastric carcinoma (case no. 11) that showed a distributed strong cytoplasmatic reactivity (figure 5). In 5 cases a scattered and weak cytoplasmatic reactivity was noted for bcl-2, which was considered to be negative too.

\section{Discussion}

The mean age of gastric carcinoma cases in this study (56 years) is significantly lower than that of population based incidence ( 70 years). Most of our cases had been operated on in advanced tumor stages, and account to a percentage of $86 \%$ in stage three and higher.

Obviously, a potential curative surgical and chemotherapeutic treatment of such advanced, poorly differentiated, and aggressive tumors is not possible. Therefore, new therapeutic approaches should be searched for.

One potential regime could be the treatment with imantinib, a substance that originally served for the inhibition of the abl-bcr fusion gene product in chronic myelogenous leukemia. It can also act as a kit tyrosine kinase inhibitor, and, therefore, its expression has been analyzed in GIST and a broad variety of other malignancies [34]. In fact, some oncologists request kit IHC stains when they are confronted with mesenchymal tumors in order to potentially apply imatinib for treatment [34]. Surprisingly, the CD117 expression in gastric carcinomas was not clearly evident although it has been investigated in numerous tumors, such as germ cell or melanocytic malignancies. We could only evaluate one article that describes an over expression of the CD117 gene in gastric carcinoma cell cultures [18].
In our study, none of the studied 38 cases displayed a CD117 expression immunohistochemically. Therefore, it seems to be unlikely, that $\mathrm{CD} 117$ plays a remarkable role in gastric carcinoma formation and progression. In addition, its potential application as a new target for therapeutic strategies is questionable. This statement holds true, even if more sensitive methods like fluorescent in situ hybridization (FISH) may detect a CD117 expression in gastric carcinoma tumor cells without corresponding IHC results. Miettinen et al. have examined kit-positive angiosarcomas for kit mutations and could not detect any abnormalities in the region typically mutated in GIST [34]. Thus, a positive IHC reaction cannot imply the application of anti kit drug regimes per se. On the other hand, mutations of CD117 genes might be present in the development of gastric carcinomas, and cannot be excluded by our study, as the applied antibodies are only directed against the "wild type" protein formation.

A similar situation was found for bcl-2 expression, which could be demonstrated intra-cytoplasmatically in only one case of a diffuse gastric carcinoma. Thus, the majority of gastric carcinomas (if not all) are immunohistochemically negative for bcl-2. These results are in agreement with the data reported by Wang and his colleagues. The authors reported only $2 \mathrm{bcl}-2$ positive cases out of 30 gastric carcinomas [47]. Fricke et al. reported a higher percentage of immunohistochemical reactivity $(5 / 24)$ for bcl2 in a study performed on 24 cases of diffuse type gastric carcinomas [15]. All of these cases were concurrently positively associated with E-cadherin mutations [15]. But there are increasing reports on $\mathrm{Bcl}-2$ reactivity in gastric cancer with much higher frequency $(11,14)$. Chen and colleagues reported $80.56 \%$ of immunohistochemical reactivity of gastric cancer cells to bcl-2 protein which was irrespective to tumor location, histologic type of cancer, and lymph node metastasis status (11). A report from Brazil shows $45 \%$ of IHC reactivity of tumor cells for bcl-2 protein (14). In both studies different types of antibody were used. In Chen study a specific method of assessment was considered for quantitative and qualitative evaluation of IHC reaction for bcl-2 (11). Considering low frequency of reactivity of gastric cancer cells in many reports including that of us, it seems to be rational to perform a large scale and inter-institutional study using specific measurements as electronic measurements to verify the exact rate of bcl-2 reactivity in gastric cancer.

\section{Conclusion}

Summarizing these data and including our own results the expression of CD117 in gastric carcinoma seems to be a very unlikely event and can not practically considered as a potential target of therapy. The expression of bcl- 2 in gastric carcinoma seems to be quite rare and currently its clinical significance is unclear. But further large studies 
needed to perform in order to verify the exact rate of bcl2 reactivity in gastric carcinoma.

\section{Acknowledgements}

The financial support of the Kerman University of Medical Sciences Research Center is gratefully acknowledged.

\section{References}

I. Akin C, Schwartz LB, Kitoh T, Obayoshi H, Worbec AS: Soluble stem cell factor receptor (CDII 7) and IL-2 receptor alpha chain (CD25) levels in the plasma of patients with mastocytosis, relationship to disease severity and bone marrow pathology. Blood 2000, 96:1267-73.

2. Araki K, Ishii G, Yokose T, Nagai K, Funai K, Kodama K, Nishiwaki Y, Ochiai $A$ : Frequent overexpression of the c-kit protein in large cell neuroendocrine carcinoma of the lung. Lung Cancer 2003, 40:173-80.

3. Ashman KL: The biology of stem cell factor and its receptor ckit. Int J Biol | 999, 31:1037-51.

4. Attoub S, Rivat C, Rodrigues S, Van Bocxlaer S, Bedin M, Bruyneel E, Louvet C, Kornprobst M, Andre T, Mareel M, Mester J, Gespach C.: The kit thyrosine kinase inhibitor STI57 I for colorectal cancer therapy. Cancer Res 2002, 62:4879-83.

5. Baselga J, Carbonell X, Castaneda-Soto NJ, Clemens M, Green M, Harvey V, Morales S, Barton C, Ghahramani P: Phase II study of efficacy, safety, and pharmacokinetics of trastuzumab monotherapy administered on a 3-weekly schedule. I Clin Oncol 2005, 23:2|62-7|

6. Bellone G, Silvestri S, Artusio E, Tibaudi D, Turletti A, Geuna M, Giachino C, Valente G, Emanuelli G, Rodech U: Growth stimulation of colorectal carcinoma cells via the c-kit receptor is inhibited by TGF- $\beta$ I. J Cell Physiol 1997, I72: I- I I.

7. Beppu K, Jaboine J, Merchant MS, Mackall CL, Thiele CJ: Effects of imatinibe mesylate on neuroblastoma tumorgenesis and vascular endothelial growth factor expression. I Natl Cancer Inst 2004, 96:46-55.

8. Blanke CD, Coia LR, Schwarz RE, Bonin SR: Gastric cancer management. In Cancer management: a multidisciplinary approach 9th edition. Edited by: Richard Pazdur, William J Hoskins, Lawrence R Coia, Lawrence D Wagman. CMP Healthcare Media; 2005:279.

9. Camirand A, Pollak M: Co-targeting IGF-IR and c-kit: synergistic inhibition proliferation and induction of apoptosis, in $\mathbf{H}$ 209 small lung cancer cells. Br J Cancer 2004, 90: 1825-9.

10. Canonico B, Felici C, Papa S: CDII7. J Biol Regul Homeost Agents 200I, I 5:90-4.

II. Chen XL, Su BS, Sun RQ, Zhang J, Wang YL: Relationship between expression and distribution of cyclooxygenase-2 and bcl-2 in human gastric adenocarcinoma. World J Gastroenterol 2005, I I:I228-|23I.

12. de Jong FA, Verweij J: Role of imatinib mesylate (Gleevecl Glivec) in gastrointestinal stromal tumors. Expert Rev Anticancer Ther 2003, 3:757-66.

13. Feng HL, Sawndlow Jl, Sporks AE, Sandra A: Deacreased level of the c-kit receptor is associated with increased apoptosis in subfertile human testes. Fertility and Sterility 1999, 71:85-9.

14. Forones NM, Carvalho AP, Giannotti-Filho O, Lourenco LG, Oshima CT: Cell proliferation and apoptosis in gastric cancer and intestinal metaplasia. Arq Gastroenterl 2005, 42:30-4.

15. Fricke E, Keller G, Becker I, Rosivatz E, Schott C, Plaschke S, Rudelius M. Hermannstadter C, Busch R, Hofler H, Becker KF, Luber B: Relationship between E-cadherin gene mutation and $\mathrm{p} 53$ gene mutation, p53 accumulation, $\mathrm{Bcl}-2$ expression and $\mathrm{Ki}-67$ staining in diffuse-type gastric carcinoma. Int / Cancer 2003, 10:60-5.

16. Gonzalez I, Andreu EJ, Panizo A, Inoges S, Fontalba A, Fernandez-Luna JL, Gaboli M, Sierrasesumaga L, Martin-Algarra S, Pardo J, Prosper F, de Alava E: Imatinib inhibits proliferation of Ewing sarcoma tumor cells mediated by the stem cell factor/KIT receptor pathway, and sensitizes cells to vincristine and doxorubicininduced apoptosis. Clin Cancer Res 2004, 10:75I-6I.

17. Hamel W, Westphal M: The road less traveled: c-kit and stem cell factor. J Neurooncol 1997, 35:327-33.

18. Hassan S, Kinoshita Y, Kawaname C, Hishik O, Fanaska C: Expression of protooncogene c-kit and its ligand stem cell factor
(SCF) in gastric carcinoma cell lines. Dig Dis Sci 1998, 35:327-33.

19. Higashiyama M, Monden T, Ogawa M, Matsuura N, Murotani M, Kawasaki Y, Tomita N, Murata A, Shimano T, Mori T: Immunohistochemical study on pancreatic secretory trypsin inhibitor (PSTI) in gastric carcinomas. Am J Clin Pathol 1990, 93:8-13.

20. Hines SJ, Organ C, Kornstein MJ, Krystal JW: Coexpression of the c-kit and stem cell factor genes in breast carcinomas. Cell Growth Differ 1995, 6:769-79.

21. Hornick JL, Fletcher CDM: Immunohistochemical staining for ckit (CDII 7) in soft tissue sarcomas is very limited in distribution. Am J Clin Pathol 2002, I I 7:188-93.

22. Immunohistochemistry Literature Database Query System [http://www.immunoquery.com/]

23. Jazirehi AR, Huerta-Yepez S, Cheng G, Bonavida B: Rituximab (chimeric anti-CD20 monoclonal antibody) inhibits the constitutive nuclear factor-\{kappa\}B signaling pathway in nonHodgkin's lymphoma B-cell lines: role in sensitization to chemotherapeutic drug-induced apoptosis. Cancer Res 2005, 65:264-76.

24. Jiang X, Gurel O, Mendiaz EA, Stearns GW, Clogston CL, Lu HS, Osslund TD, Syed RS, Langley KE, Hendrickson WA: Structure of active core of human stem cell factor and analysis of binding to its receptor kit. EMBO J 2000, 19:3192-203.

25. Kemmer K, Corless CL, Fletcher JA, McGreevey L, Haley A, Griffith $D$, Cummings OW, Wait C, Town A, Heinrich MC: kit mutations are common in testicular seminomas. Am J Pathol 2004, 164:305-13.

26. Kim R, Emi M, Matsuura K, Tanabe K: Therapeutic potential of antisense (AS) Bcl-2 as a chemosensitizer for patients with gastric and breast carcinoma. Gan To Kagaku Ryoho 2005, 32: $1540-5$.

27. Kindler T, Breitenbuecher F, Marx A, Beck J, Hess G, Weinkauf B, Duyster J, Peschel C, Kirkpatrick C], Theobald M, Gschaidmeier H, Huber C, Fischer T: Efficacy and safety of imatinib in adult patients with c-kit-positive acute myeloid leukemia. Blood 2004, I 03:3644-54.

28. Lahm H, Amstad P, Yilmaz A, Borbenyi Z, Wyniger J, Fischer JR, Suardet L, Givel JC, Odartchenko N: Interlukin 4 down-regulates expression of c-kit and stem cell factor in human colorectal carcinoma cells. Cell Growth Differ 1995, 6: I II I-8.

29. Lauren F: The two histological main types of gastric carcinoma: diffuse and so-called intestinal type carcinoma. An attempt to histoclinical classification. Acta Pathol Microbiol Scand 1995, 64:31-40.

30. Levesque JP, Hendy J, Winkler IG, Takamatsu Y, Simmons PJ: Granulocyte colony stimulating factor induces the release in the bone marrow of proteases that cleave c-kit receptor (CDII 7) from the surface of hematopoietic progenitor cells. Exp Hematol 2003, 3 I: 109-17.

3I. Liu HF, Liu WW, Wang GA, Teng XC: Effect of Helicobacter pylori infection on Bax protein expression in patients with gastric precancerous lesions. World J Gastroenterol 2005, I I:5899-590I.

32. Liu W, Guo QL, You QD, Zhao L, Gu HY, Yuan ST: Anticancer effect and apoptosis induction of gambogic acid in human gastric cancer line BGC-823. World J Gastroenterol 2005, I I:3655-3659.

33. Matsui J, Wakabayashi T, Asoda M, Yoshimatsuk O: Stem cell factor/c-kit signaling promotes the survival, migration, and capillary tube formation of human umbilical vein endothelial cells. J Biol Chem 2004, 279:186-7.

34. Miettinen M: New challenges in the identification of gastrointestinal stromal tumors and other possible KIT-deriven tumors. Am J Clin Pathol 2002, I I 7: I83-185.

35. Nakamura $Y$, Tajima F, Ishiga K, Yamazaki H, Oshimura M, Shiota G, Murawaki Y: Soluble c-kit receptor mobilizes hematopoietic stem cells to peripheral blood in mice. Exp Hematol 2004, 32:390-6.

36. Nakatani T, Marui T, Yamamoto T, Hitora T, Akisue T, Kawamoto T, Nagira K, Fujita I, Matsumoto K, Yoshiya S, Kurosaka M: Expression of stem cell factor and c-kit in human malignant fibrous histiocytoma cell line (TNMYI). Anticancer Res 23:2329-33.

37. Nishida K, Tsukamoto T, Uchida K, Takahashi T, Takahashi T, Ueda $\mathrm{R}$ : Introduction of the c-kit gene leads to growth suppression 
of breast cancer cell line, MCF-7. Anticancer Res 1996, 16:3397-402.

38. Ramadori G, Fuzesi L, Grabbe E, Pieler T, Armbrust T: Successful treatment of hepatocellular carcinoma with thyrosine kinase inhibitor imatinib mesylate in a patient with liver cirrhosis. Anticancer Drugs 2004, 15:405-9.

39. Raspollini MR, Paglierani M, Taddei GL, Villanucci A, Amunni G, Taddei A: The protooncogene c-kit is expressed in leiomyosarcoma of the uterus. Gynecol Oncol 2003, 93:718.

40. Reed J, Ouban A, Schickor FK, Muraca P, Yeatman T, Coppola D: Immunohistochemical staining for c-kit (CDII7) is a rare event in colorectal carcinoma. Comment in J Clin Oncol 2003, 21:3885-6. discussion 3887-9

4I. Reedy MV, Johnson RL, Erickson CA: The expression patterns of c-kit and SI in chicken embryos suggest unexpected role for these agents in somite and limb development. Gene Expression Patterns 2003, 3:53-58.

42. Romagnoli S, Graziani D, Bramerio M, Gambacorta M, Colombo P, Roncalli M, Coggi G, Bosari S: Imunohistochemical profile and ckit mutations in gastrointestinal stromal tumors. Pathol Res Pract 2005, 201:71-8I.

43. Rosai J, Ed: Ackerman's Surgical Pathology 9th edition. St. Louis: Mosby; 2004.

44. Sandberg AA, Bridge JA: Updates on cytogenetics and molecular genetics of bone and soft tissue tumors, gastrointestinal stromal tumors. Cancer Genet Cytogenet 2002, I35: I-22.

45. Spiekermann K, Faber F, Voswinckel R, Hiddemann W: The protein tyrosine kinase inhibitor SU56/4 inhibits VEGF-induced endothelial cell sprouting and induces growth arrest and apoptosis by inhibition of c-kit in AML cells. Exp Hematol 2002, 30:767-73.

46. Surgical Oncology Net [http://www.surgical-oncology.net]

47. Wang J, Chi DS, Kalin GB, Sosinski C, Miller LE, Burja I, Thomas E: Helicobacter pylori infection and oncogene expressions in gastric carcinoma and its precursor lesions. Dig Dis Sci 2002, 47:107-13.

48. Warshamana-Greene GS, Litz J, Buchdunger E, Hofmann F, GarciaEcheverria C, Krystal GW: The insulin-like growth factor I (IGF-I) receptor kinase inhibitor NVP-ADW742 in combination with STI57I decline spectrum of dependence of small cell lung cancer on IGF-stem cell factor signaling. Mol Cancer Ther 2004, 3:527-35.

49. Watanabe H, Tokuyama $\mathrm{H}$, Ohta $\mathrm{H}$, Satomura $\mathrm{Y}$, Okai T, Ooi A, Mai $M$, Sawabu N: Expression of placental alkaline phosphatase in gastric and colorectal cancers. An immunohistochemical study using the prepared monoclonal antibody. Cancer 1990, 66(I 2):2575-82.

50. Xia HH, Talley NJ: Apoptosis in gastric epithelium induced by helicobacter pylori infection: implications in gastric carcinogenesis. Am J Gastroenterol 200I, 96:16-26.

5I. Yamamoto T, Nakatani T, Marui T, Akisue T, Fujita I, Matsumoto K, Hitora T, Kawamoto T, Nagira K, Kurosaka M: Expression of stem cell factor and lack of c-kit expression in malignant fibrous histiocytoma of soft tissue. Anticancer Res 2003, 23:4305-8.

\section{Publish with Bio Med Central and every scientist can read your work free of charge}

"BioMed Central will be the most significant development for disseminating the results of biomedical research in our lifetime. "

Sir Paul Nurse, Cancer Research UK

Your research papers will be:

- available free of charge to the entire biomedical community

- peer reviewed and published immediately upon acceptance

- cited in PubMed and archived on PubMed Central

- yours - you keep the copyright
BioMedcentral 